\title{
PENGEMBANGAN SISTEM MEMBACA AL-QUR'AN DENGAN METODE MULTIMEDIA DEVELOPMENT LIFE CYCLE
}

\author{
Suherman Herman ${ }^{1}$, Sunny Samsuni ${ }^{2}$, Fathurohman Fathurohman ${ }^{3}$ \\ 1'suherman.unsera@gmail.com, ${ }^{2}$ sunnysamsuni@gmail.com, 3omanfathur79@gmail.com \\ 123Jurusan Teknik Informatika, Fakultas Teknologi Informasi, \\ Universitas Serang Raya, Banten
}

\begin{abstract}
Abstrak
Al-Qur'an ialah Kitab Suci yang merupakan sumber utama dan pertama dalam ajaran Islam. Penting bagi kita sebagai umat muslim untuk belajar mengenai cara membaca Al-Qur'an dengan baik dan benar. Penelitian ini menggunakan pendekatan 2 (dua) metode yaitu metode pengembangan sistem Multimedia dan metode pembelajaran yang digunakan adalah dengan menggunakan metode Tartil. Dengan menggunakan pendekatan dua metode ini diharapkan akan lebih menarik minat baca siswa serta dapat mempercepat cara membaca Al-Qur'an dengan baik dan benar. Hasil dari penelitian ini berupa aplikasi berbasis android yang dapat membantu belajar membaca Al-Quran dengan baik dan benar. Aplikasi ini diuji dengan menggunakan metode black box yang menunjukkan semua fungsi berjalan dengan benar $100 \%$ sesuai dengan apa yang diharapkan. Pengujian dilakukan juga dengan menggunakan metode kuisioner dan observasi untuk mengetahui perbandingan kemajuan siswa sebelum dan sesudah menggunakan aplikasi. Hasilnya menunjukkan 85\% mengalami kemajuan setelah menggunakan aplikasi dan hanya $15 \%$ saja yang tidak mengalami kemajuan.
\end{abstract}

Kata Kunci: Multimedia, Media Pembelajaran, Aplikasi, Metode Tartil, Al-Qur’an.

\begin{abstract}
Al-Qur'an is the Holy Book which is the main and first source in Islamic teachings. It is important for us as Muslims to learn about how to read the Qur'an properly. This research uses two method approach namely Multimedia System Development method and learning method used is to use Tartil method. By using this two-method approach it is hoped that it will be more interesting for students to read and be able to accelerate how to read the Qur'an properly. The results of this research are in the form of an android-based application that can help to learn and read the Al-Qur'an properly. This application is tested using the Black Box method that shows all functions are running properly $100 \%$ according to what is expected.. The results show $85 \%$ progressed after using the application and only $15 \%$ did not progress.
\end{abstract}

Keywords: Multimedia, Learning Media, Applications, Tartil Method, Al-Qur'an.

\section{Pendahuluan}

Al-Qur'an ialah kitab suci yang merupakan sumber utama dan pertama dalam ajaran Islam, menjadi petunjuk kehidupan umat manusia, yang diturunkan Allah SWT kepada Nabi Suci Rasulullah Muhammad S.A.W. sebagai salah satu rahmat yang tidak ada bandingannya bagi alam semesta. AlQur'an juga merupakan sebaik-baik bacaan bagi orang Mu'min. Mempelajari serta mengajarkannya merupakan sebaik-baiknya manusia, sesuai sabda Nabi Suci Rasulullah Muhammad S.A.W yang ditulis dalam kitab shahih Imam Al-Bukhari, yang meriwayatkan sebuah hadits dari Hajjaj bin Minhal dari Syu'bah dari Alqamah bin Martsad dari Sa'ad bin Ubaidah dari Abu Abdirrahman As-Sulami dari Utsman bin Affan Radhiyallahu'anhu [2] :

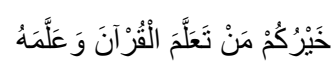

"Sebaik-baik kalian adalah orang yang belajar Al-Qur`an dan mengajarkannya."

Begitu pentingnya membaca Al-Qur'an dengan baik dan benar menjadi landasan dasar kewajiban untuk mempelajari metodologinya, sehingga membacanya menjadi Tartil dan tidak merubah makna isi dari Al-Qur'an tersebut. Hal ini berdasarkan penyataan para ulama qurro' (ahli 
ILKOM Jurnal Ilmiah Volume 11 Nomor 2 Agustus 2019 Terakreditasi peringkat 3 SK. No. 28/E/KPT/2019

baca Al-Qur'an) yang mu'tabar (diakui keilmuannya), yang telah bersepakat bahwa hukum membaca Al-Qur'an dengan tajwidnya ialah fardhu (harus/wajib) [2]

Namun, pandangan teoritik keagamaan di atas yang seharusnya dihayati dan diamalkan tidak berbanding lurus dengan realitas belakangan ini. Saat ini, animo belajar mengaji Al-Qur'an pada siswa-siswi Sekolah Menengah Kejuruan (SMK) dirasa telah menurun, terutama di SMK Kesehatan Husada Pratama Kota Serang. Hal ini berdasarkan data kuesioner sebanyak 100 responden yang disebar kepada para siswa-siswi SMK Kesehatan Husada Pratama, yang pada umumnya berpandangan bahwa belajar membaca Al-Qur'an merupakan pembelajaran yang cukup sulit dipelajari. Disamping itu, terbatasnya waktu belajar membaca AI-Qur'an juga merupakan indikator permasalahan lainnya dalam mempelajari tata cara membaca Al-Qur'an yang baik dan benar. Pembelajaran-pembelajaran yang konvesional juga semakin tertinggal dengan arus teknologi yang begitu cepat dan serba praktis.

Media pembelajaran mengenai cara membaca Al-Qur'an saat ini banyak ditemui dipasaran, seperti buku. Namun pada buku penyampaian materi hanya berupa teks atau gambar diam saja, sehingga siswa tidak berminat untuk mempelajarinya, hal ini akan mengakibatkan menurunnya animo siswa dalam belajar membaca Al-Qur'an, secara mandiri siswa juga merasa kesulitan membaca AlQuran dari sisi membaca yang Al-Qur'an dan panjang pendeknya bacaan, dan juga terbatasnya waktu belajar membaca Al-Qur'an yang harus selalu didampingi oleh seorang guru. Saat ini, para siswa memerlukan adanya media pembelajaran lain yang mudah dan praktis, serta tepat dalam mempelajarinya [4].. Adanya media lain selain buku/modul dirasa akan juga dapat mempermudah dalam proses pembelajaran [7].

Dengan menggunakan aplikasi multimedia juga akan lebih menarik dan menyenangkan dalam mempelajarinya [6]. Tak hanya menarik dan mudah, media pembelajaran juga harus sesuai dengan buku/modul yang ada sehingga tersampaikan secara tepat.

Oleh karena itu perlunya sebuah aplikasi sebagai sarana pembelajaran secara mandiri untuk mempelajari cara belajar membaca Al-Qur'an yang baik dan benar dengan menggunakan Construct. Aplikasi ini berisi materi pembelajaran membaca Al-Qur'an metode Tartil (Cepat, Tepat, dan Terampil) dengan membandingkan hasil buah karya Tubagus (Tb) [3] , seorang tokoh Banten yang konsisten dalam mengajarkan ilmu Al-Qur'anul Karim. Kelebihan aplikasi hasil penelitiian ini yaitu memuat tentang pengenalan huruf hijaiyah agar mudah dikuasai dan tanda baca secara detail, mudah dimengerti dan digunakan oleh para pelajar yang ingin mempelajari tata cara membaca Al'Qur'an,dilengkapi keterangan pembelajaran yang membantu para pelajar dalam mempelajari hukum bacaannya, dilengkapi dengan animasi dan suara sehingga menarik bagi para pelajar dalam belajar cara membaca Al'Qur'an dengan metode tartil, adanya latihan soal dalam bentuk game interaktif yang dimaksudkan sebagai evaluasi dari setiap materi yang diajarkan dan meningkatkan daya ingat pelajar dalm pembelajaran cara membaca Al'Qur'an dengan metode tartil, dan adanya canvas tulis untuk melatih siswa dalam menulis huruf/kalimat hijaiyah.

Ai Adhayani dan Dewi Tresnawati [8] dalam jurnalnya menggunakan Metode Luther". Dengan menggunakan metode pengembangan perangkat lunak sistem multimedia oleh Luther-Sutopo, dapat menguji aplikasi menggunakan pengujian Alpha yang dilakukan untuk menemukan kesalahan terhadap aplikasi dan pengujian Beta yang dilakukan oleh pengguna akhir.Kelebihan dari penelitian ini adalah sederhana dan mudah dipelajari karena menggunakan metode iqro yang sudah lama dikenal oleh maysarakat. Kekurangan dari ada pada aplikasi yang dibuat karena kualitas audio yang disampaikan kurang memuaskan dan terlalu cepat dalam memberikan pelajaran iqro tersebut.

Iswatun Khasanah dan Hanif Al Fatta [4] bahwa selama ini ketergantungan siswa akan guru tajwid masih sangat tinggi. Hal ini karena ilmu tajwid sangat erat hubungannya dengan bagaimana melafalkan bunyi bacaan Al-Qur'an dengan baik. Kelemahan dari penelitian ini adalah penyampaian materi kepada peserta tidak menggunakan metode apapun seperti taritil mapupun iqro sedangkan kelebihannya adalah aplikasi dibuat lebih interaktif sehingga banyak disukai oleh pengguna.

\section{Metode}

\subsection{Metode Tartil}

Dalam bukunya [3] menjelaskan, secara keseluruhan metode Tartil ini dibagi kedalam 5 materi Pokok yang terdiri dari 20 langkah:

1. Mengenal huruf hijaiyah terpisah dan bersambung.

Pada materi ini, terdiri dari 3 langkah; Pertama, peserta didik diperkenalkan hanya 15 huruf hijaiyah yakni Alif sampai Dlod, dengan cara perbaris seperti; A, Ba, Ta, Tsa - Ja, Cha, Kho, - Da, Dza, Ro, Za, - Sa, Sya, Sho, Dlo. Setelah mengenal peserta didik boleh mengulang secara 
bersama-sama dengan irama atau lagu supaya mengikat ingatan anak dengan tetap memperhatikan ketepatan membaca (makhraj). Kemudian dilanjutkan pada huruf hijaiyah berbaris acak. Setelah lancar, lanjutkan pada bab latihan untuk mempelancar bacaan dan makhraj dan jangan sampai bacaan dibaca panjang. Untuk peserta didik privat yang cepat mengusai materi boleh dilanjutkan kemateri berikutnya. Sementara peserta didik yang lambat, materi harus difokuskan pada yang sulit, dengan demikian anak yang cepat tidak terhambat dan yang lambat akan lebih mantap meski telat.

Kedua, peserta didik diperkenalkan sebagian huruf hijaiyah lainnya yakni; Tho, Dzo,'A, Gho, - Fa, Qo, Ka - La, Ma, Na, Wa,- Ha, A, Ya .

Ketiga, peserta didik diajarkan huruf bersambung perbaris seperti, A, Ba, Ta, Tsa = AbaTaTsa. Bila membacanya dipanjang-panjangkan seperti pada maetri latihan, boleh membacanya secara terputus seperti: Tsa-Ba-Ta, kemudian ulang sekali lagi dengan membaca secara langsung (tidak terputus) seperti TsaBaTa. Jika belum lancar jangan dilanjutkan kehalaman berikutnya.

2. Mengenal Tanda Baca

Pada materi ini, terdiri dari 3 langkah; Keempat, dan Kelima, Peserta didik diperkenalkan huruf bersambung berbaris kasrah (i) dan dlomah (u). Demi menjaga ketepatan membaca, tetap perhatikan jangan sampai bacaan dibaca panjang dan i berbunyi ie atau u berbunyi ou.

Keenam, peserta didik diperkenalkan tanda baca tanwin yang dibaca secara bersama-sama seperti: Jaza-a=Jaza-an. Qori-a=Qori-an. Jaro-u=Jaro-un. Bacalah dengan tetap memperhatikan bacaan, jangan sampai tanwin dibaca panjang dan berbunyi miring seperti Un berbunyi On atau In berbunyi len atau An berbunyi Aen.

3. Mengenal Bacaan Panjang

Pada materi ini, terdiri dari 3 langkah (Langkah 7, 8 dan 9), yang masing-masing dititik beratkan pada bacaan panjang. Untuk memudahkan bacaan peserta didik dibantu dengan irama ketukan. Satu ketukan (.) untuk bacaan pendek, dan dua ketukaan (..) untuk bacaan panjang, yang dimulai dari arah kanan ke kiri.

4. Mengenal Bacaan Melebur dan Berdengung

Pada materi ini, terdiri dari 9 langkah; Sepuluh, peserta didik diperkenalkan tanda baca sukun atau 'mati'. Pada materi ini, peserta didik diperkenalkan huruf nun dan mim sukun karena lebih mudah dan sering dijumpai dalam Al-Qur'an. Dalam membacanya perhatikan, jangan sampai dibaca memantul seperti: Anhum dibaca Anehume, dan huruf-huruf lainnya, karena yang dibaca memantul ketika sukun atau waqof hanya huruf Qof, Tho, Ba, Jim, dan Dal atau yang disebut Qolqolah.

Sebelas, pengenalan tanda baca syiddah atau tasyjid. Peserta didik biasanya akan lebih mudah dalam menangkap, hanya terkadang sering lupa dalam membacanya. Maka, ingat-ingatlah dengan cara mengulang-ulang.

Duabelas, Peserta didik diajarkan kalimat yang di waqof atau kalimat berhenti dengan tetap memperhatikan jangan sampai dibaca memantul selain huruf qolqolah. Peserta didik juga diajarkan perluasan materi seperti Ta Marbuthoh atau Ta Bulat dibaca Ha bila disukunkan dan fathahtain dibaca panjang hilang tanwinnya bila diwaqof.

Tigabelas dan Empatbelas, peserta didik diajarkan kalimat Al-Qomariyah dan Asy-Syamsiyah. Bila dalam tahapan ini belum begitu lancar diharuskan mengulangi setiap tahapannya agar tepat dalam membaca. Peserta didik juga diajarkan perluasaan materi seperti bacaan yang dibaca lebih panjang.

Limabelas, Peserta didik diajarkan huruf yang dibaca mendengung ketika bertemu nun sukun atau tanwin (Ya, Nun, Mim, Wau), contohnya: Manyasyaau dibaca Manyyasyaau.

Enambelas, peserta didik diajarkan mengenai huruf yang dibaca mendengung dan berbunyi "NG" ketika bertemu nun sukun datau tanwin, contohnya; Innalinsana dibaca Innalingsana. Huruf tersebut berjumlah 15 yaitu, Ta, Tsa, Ja, Da, Dza, Za, Sa, Sya, Sho, Dlo, Tho, Zho, Fa, Qo, Ka.

Tujuhbelas, Peserta didik diajarkan huruf mendengung Mim sukun bertemu dengan Mim dan Ba yang harus dibaca mendengung. Diajarkan pula materi lain seperti huruf Mim dan Nun bertasydid dibaca dengan mendengung. Dan penyebutan Lam Lafadz Allah yang dibaca tebal dan tipis.

Delapanbelas, Pada langkah ini peserta didik dikenalkan dengan nun mati atau tanwin berubah bunyi menjadi mim dan mendengung. Contohnya, Minba'di dibaca Mimmba'di. Setiap bacaan hanya dibaca dua sampai tiga ketukan panjang, tidak lebih.

5. Mengenal Bacaan Melebur Tanpa Dengung, Waqof, Bacaan Memantul.

Pada materi ini, terdiri dari 2 langkah; Sembilanbelas, peserta didik diajarkan tanwin atau nun sukun bertemu huruf Lam dan Ro dibaca tasydid tidak mendengung. Peserta didik juga diajarkan 
ILKOM Jurnal Ilmiah Volume 11 Nomor 2 Agustus 2019 Terakreditasi peringkat 3 SK. No. 28/E/KPT/2019

tanwin atau nun sukun bertemu huruf tenggorokan (hamzah, ha, 'ain, cha, ghin, kho) dibacanya jelas tidak mendengung.

Duapuluh, Peserta didik dilatih guna melancarkan bacaan dengan tetap memperhatikan semua materi yang sudah dipelajari. Pada bagian ini, peserta didik juga diajarkan tanda baca waqof, cara mewaqofkan, wau yang dianggap tidak ada, bacaab gharib dan lainnya.

\subsection{Metode Pengembangan}

Metode Luther merupakan metode pengembangan perangkat lunak multimedia dimana metode yang digunakan dalam pengembangan multimedia ini adalah Multimedia Development Life Cycle. Pengembangan metode multimedia ini dilakukan berdasarkan enam tahap (Gambar 1), yaitu concept (pengonsepan), design (pendesignan), material collecting (pengumpulan materi), assembly (pembuatan), testing (pengujian), dan distribution (pendistribusian). Keenam tahap ini tidak harus berurutan dalam praktiknya, tahap-tahap tersebut dapat saling bertukar posisi. Meskipun begitu, tahap concept memang harus menjadi hal yang pertama kali dikerjakan. [5].

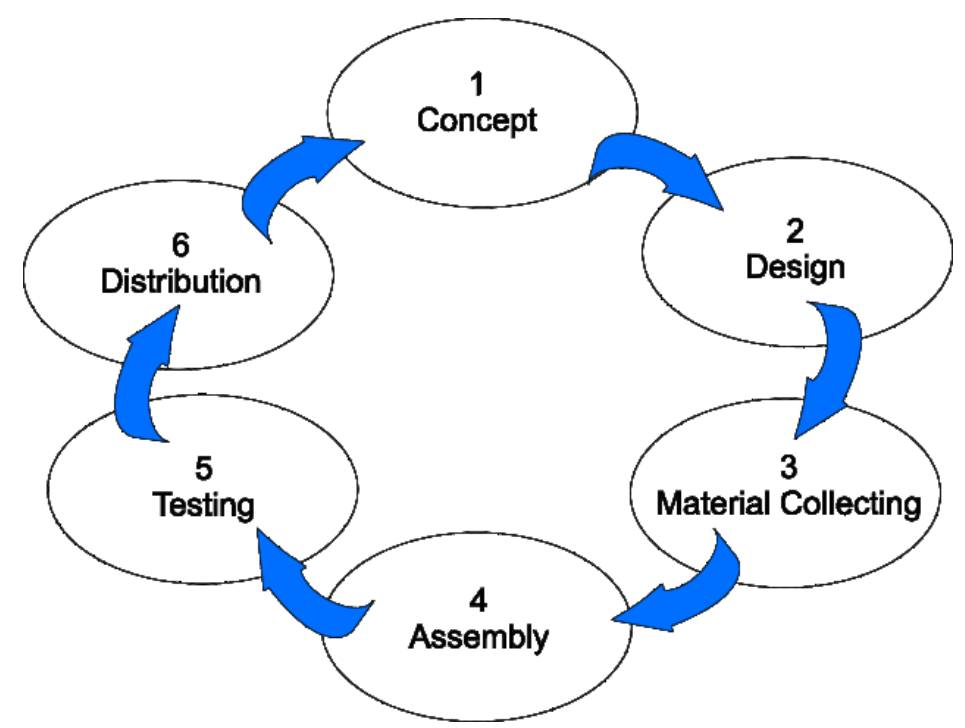

Gambar 1. Metode MDLC Luther-Sutopo

\section{Concept}

Tahap concept (konsep) yaitu menentukan tujuan dan siapa pengguna program (identifikasi audience), macam aplikasi (presentasi, interaktif, dan lain-lain), tujuan aplikasi (informasi, hiburan, pelatihan, dan lain-lain), dan spesifikasi umum. Dasar aturan untuk perancangan juga ditentukan pada tahap ini, seperti ukuran aplikasi, target, dan lain-lain. Tujuan dan pengguna akhir program berpengaruh pada nuansa multimedia sebagai pencerminan dari identitas organisasi yang menginginkan informasi sampai pada pengguna akhir. Karakteristik pengguna termasuk kemampuan pengguna juga perlu dipertimbangkan karena dapat mempengaruhi pembuatan design.

\section{Design}

Design (perancangan) adalah membuat spesifikasi secara rinci mengenai arsitektur program, gaya, tampilan dan kebutuhan material atau bahan untuk program. Spesifikasi dibuat cukup rinci sehingga pada tahap berikutnya, yaitu material collecting dan assembly tidak diperlukan keputusan baru, tetapi menggunakan apa yang sudah ditentukan pada tahap design. Namun demikian, sering terjadi penambahan bahan atau bagian aplikasi ditambah, dihilangkan, atau diubah pada awal pengerjaan proyek. Tahap ini menggunakan storyboard untuk menggambarkan deskripsi tiap scene, dengan mencantumkan semua objek multimedia dan tautan ke scene lain dan bagan alir (flowchart) untuk menggambarkan aliran dari satu scene ke scene lain.

3. Material Collecting

Material Collecting (pengumpulan bahan) adalah tahap pengumpulan bahan yang sesuai dengan kebutuhan yang dikerjakan. Bahan-bahan tersebut, antara lain gambar clip art, foto, animasi, video, audio, dan lain-lain yang dapat diperoleh secara gratis atau dengan pemesanan kepada pihak lain sesuai dengan rancangannya. Tahap ini dapat dikerjakan secara parallel dengan tahap assembly. 
ILKOM Jurnal Ilmiah Volume 11 Nomor 2 Agustus 2019

Terakreditasi peringkat 3 SK. No. 28/E/KPT/2019

\section{Assembly}

Tahap assembly (pembuatan) adalah tahap pembuatan semua objek atau bahan multimedia. Pembuatan aplikasi berdasarkan storyboard, bagan alir (flowchart), dan struktur navigasi yang berasal pada tahap design.

\section{Testing}

Tahap testing (pengujian) dilakukan setelah menyelesaikan tahap pembuatan (assembly) dengan menjalankan aplikasi / program dan dilihat apakah ada kesalahan atau tidak. Tahap pertama pada tahap ini disebut juga sebagai tahap pengujian alpha (alpha test) yang pengujiannya dilakukan oleh pembuat atau lingkungan pembuatnya sendiri. Setelah lolos dari pengujian alpha, pengujian beta yang melibatkan pengguna akhir akan dilakukan.

6. Distribution

Tahap ini aplikasi akan disimpan dalam suatu media penyimpanan. Tahap ini juga dapat disebut tahap evaluasi untuk pengembangan produk yang sudah jadi supaya menjadi lebih baik. Hasil evaluasi ini dapat digunakan sebagai masukan untuk tahap concept pada produk selanjutnya.

\section{Hasil dan Pembahasan}

Hasil yang dicapai dari penelitian ini adalah Aplikasi Pembelajaran Membaca Al-Qur'an dengan Metode Tartil yang berisi tentang materi Metode Tartil dan tambahan latihan soal serta latihan menulis.

\section{Keterangan Pembelajaran}

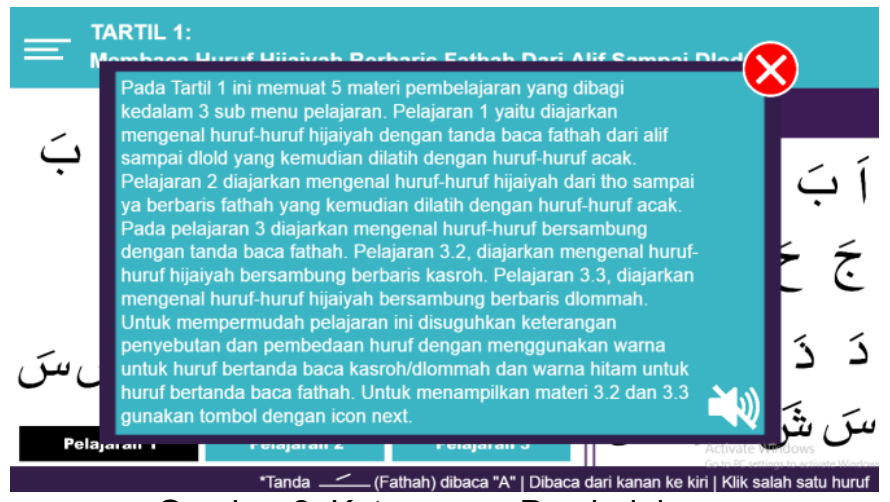

Gambar 2. Keterangan Pembelajaran

Gambar di atas menjelaskan tampilan keterangan pembelajaran. Keterangan ini dimaksudkan untuk mempermudah pengguna dalam mempelajari materi yang disuguhkan. Untuk menjadikan tampilan menarik, teks pada keterangan pembelajaran ini berupa teks dengan animasi jalan dan dengan menggunakan suara.

\section{Canvas Tulis}

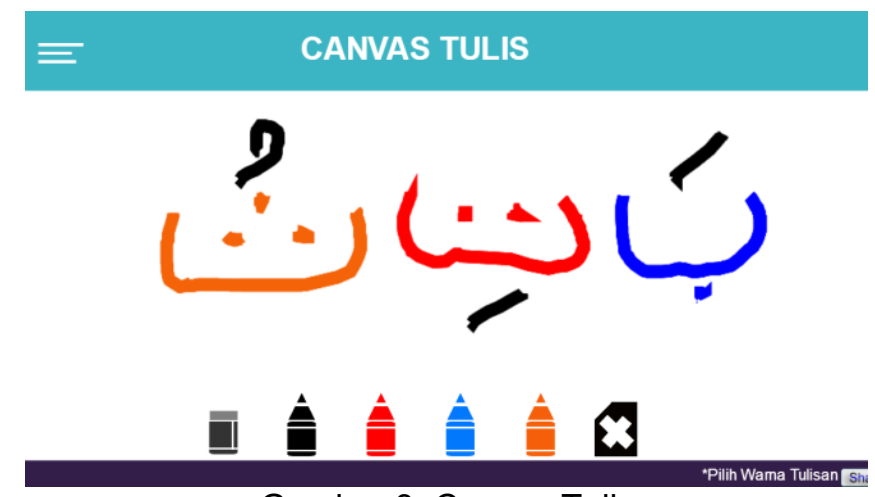

Gambar 3. Canvas Tulis

Gambar di atas menjelaskan tampilan canvas tulis. Halaman ini dimaksudkan untuk melatih siswa/pelajar dalam menulis huruf atau kalimat hijaiyah. Disamping itu halaman ini untuk digunakan 
ILKOM Jurnal Ilmiah Volume 11 Nomor 2 Agustus 2019

Terakreditasi peringkat 3 SK. No. 28/E/KPT/2019

para guru/pengajar dalam menuliskan contoh-contoh huruf atau kalimat lain dari materi yang sudah disediakan.

\subsection{Pengujian Aplikasi}

Pengujian ini bertujuan untuk mengetahui apakah aplikasi atau sistem yang dirancang dapat bekerja sesuai dengan perancangan yang telah ditetapkan. Pengujian yang dilakukan pada aplikasi ini adalah dengan cara pengujian secara fungsional [1]. Metode yang digunakan dalam pengujian ini adalah pengujian Black Box yang berfokus pada persyaratan fungsional dari sistem yang dibangun. Pengujian sistem melibatkan pakar IT dan tutor Metode Tartil. Hasilnya aplikasi dapat menampilkan dan berjalan sesuai dengan apa yang diharapkan.

\subsection{Pengujian Pre-Test dan Post-Test}

Pengujian dalam penelitian ini dilakukan di SMK Kesehatan Husada Pratama Kota Serang yang beralamat di JI Mayor Muslich Lingkar Selatan Cikulur Jelawe Rt. 03/04 Serang. Sedangkan Kuesioner tersebut kemudian diisi oleh guru yang mengamati 40 responden dari peserta didik, dalam hal ini guru berperan langsung sebagai pengamat. Kuesioner dibagikan dalam dua tahapan yaitu tahap pertama sebelum menggunakan aplikasi pembelajaran (pre-test), kedua dibagikan sesudah menggunakan aplikasi pembelajaran yang telah dibuat (post-test) untuk nilai 100 siswa. Berikut hasil rekapitulasi yang di peroleh dari angket yang telah di isi oleh responden guru.

Tabel 1. Hasil Rekapitulasi Pre-Test

\begin{tabular}{|c|c|c|c|c|c|c|c|c|c|}
\hline Pernyataan & SS & S & C & TS & STS & Jumlah & Skor & Index & Ket \\
\hline 1 & 0 & 12 & 5 & 16 & 7 & 40 & 102 & $51 \%$ & Cukup \\
\hline 2 & 2 & 18 & 6 & 9 & 5 & 40 & 123 & $61,5 \%$ & Setuju \\
\hline 3 & 16 & 12 & 6 & 4 & 2 & 40 & 156 & $78 \%$ & Setuju \\
\hline 4 & 6 & 12 & 16 & 4 & 2 & 40 & 136 & $68 \%$ & Setuju \\
\hline 5 & 17,2 & 11 & 7 & 3 & 1 & 39,2 & 158 & $79 \%$ & Sangat Setuju \\
\hline 6 & 1 & 5 & 5 & 12 & 19 & 42 & 83 & $41,5 \%$ & Tidak Setuju \\
\hline 7 & 1 & 7 & 18 & 8 & 6 & 40 & 109 & $54,5 \%$ & Cukup \\
\hline 8 & 19 & 12 & 6 & 2 & 1 & 40 & 166 & $83 \%$ & Sangat Setuju \\
\hline
\end{tabular}

Tabel 2. Hasil Rekapitulasi Post-Test

\begin{tabular}{|c|c|c|c|c|c|c|c|c|c|}
\hline Pernyataan & SS & S & C & TS & STS & Jumlah & Skor & Index & Ket \\
\hline 1 & 9 & 24 & 5 & 2 & 0 & 40 & 160 & $80 \%$ & Sangat Setuju \\
\hline 2 & 6 & 26 & 5 & 3 & 0 & 40 & 155 & $77,5 \%$ & Setuju \\
\hline 3 & 2 & 26 & 8 & 4 & 0 & 40 & 146 & $73 \%$ & Setuju \\
\hline 4 & 3 & 18 & 15 & 4 & 0 & 40 & 140 & $70 \%$ & Setuju \\
\hline 5 & 2 & 15 & 19 & 3 & 1 & 40 & 134 & $67 \%$ & Setuju \\
\hline 6 & 14 & 19 & 6 & 1 & 0 & 40 & 166 & $83 \%$ & Sangat Setuju \\
\hline 7 & 21 & 8 & 11 & 0 & 0 & 40 & 170 & $85 \%$ & Sangat Setuju \\
\hline 8 & 17 & 11 & 8 & 2 & 2 & 40 & 159 & $79,5 \%$ & Setuju \\
\hline
\end{tabular}

Keterangan: SS : Sangat Setuju, S : Setuju, N : Netral, TS : Tidak Setuju, STS : Sangat Tidak Setuju.

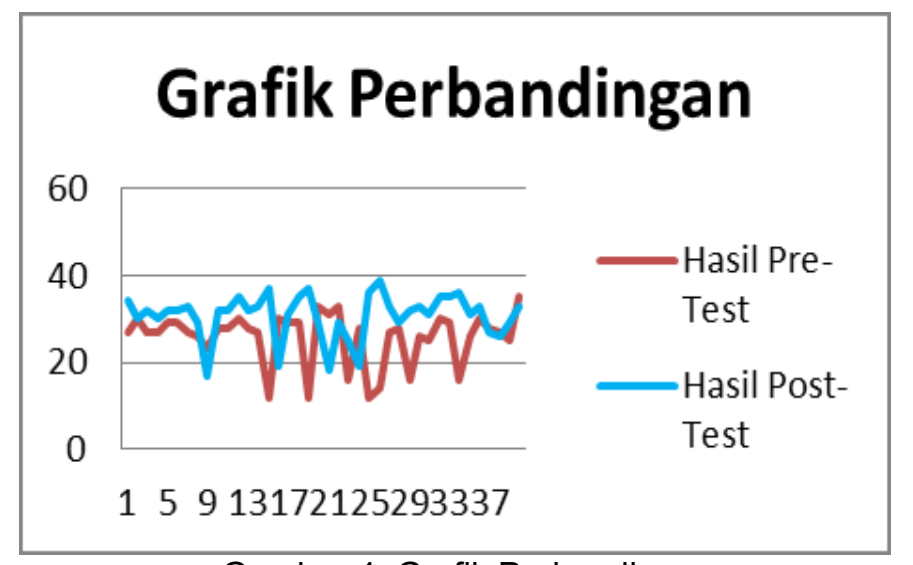

Gambar 4. Grafik Perbandingan 
ILKOM Jurnal Ilmiah Volume 11 Nomor 2 Agustus 2019

Terakreditasi peringkat 3 SK. No. 28/E/KPT/2019

\section{Kesimpulan dan Saran}

Simpulan dari penelitian ini adalah Aplikasi belajar membaca Al-Qur'an dengan metode Tartil yang dibuat menggunakan multimedia ini telah berjalan sesuai dengan yang diharapkan berdasarkan hasil pengujian BlackBox yang dilakukan oleh Pakar IT Multimedia dan Tutor Metode Tartil. Penerapan metode Tartil (Cepat, Tepat, dan Terampil) kedalam aplikasi bersistem android ini dinilai cukup signifikan dalam mempengaruhi minat belajar tambahan membaca Al-Qur'an serta dapat meningkatkan kemampuan pemahaman cara membaca Al-Qur'an, yaitu berdasarkan hasil Pre-Test dan Post-Test. Dengan menggunakan aplikasi pembelajaran berbasis android ini pengguna dapat menyerap materi dengan cepat dan efisien karena ditambahkan fasilitas rule, animasi, suara, dan tanda titik titik sebagai penanda panjang dan pendeknya bacaan. Selain itu, dengan menggunakan aplikasi ini pengguna lebih mudah dalam mempelajari materi pembelajaran yang diajarkan. Hal ini bedasarkan hasil pengujian yang dilakukan langsung oleh siswa-siswi SMK Kesehatan Husada Pratama Kota Serang dari berbagai kelas. Aplikasi yang dibangun juga dapat diterima sesuai dengan kebutuhan pengguna baik dari segi isi materi, visualisasi, suara dan kenyamanan menggunakan aplikasi. Dari hasil pengujian sistem juga, sistem yang baru dapat dikatakan lebih user friendly, lebih menarik dan lebih informatif.

\section{Daftar Pustaka}

[1] Jogiyanto H.M, "Analisis Dan Desain," Analisis Dan Desain. 2005.

[2] Afriyansyah, Dedi, Aplikasi Mobile Pembelajaran Hijaiyah dan Iqra Sebagai Sarana Membaca Al-Qur'an Berbasis Android pada Madrasah Ibtidaiyah Negeri Sungailiat. Bangka Belitung: Teknik Informatika STMIK Atma Luhur Pangkalpinang, 2015.

[3] Al-Ahmad, Tb. Chudori, Metode TARTIL (Cepat, Tepat, dan Terampil). Serang: Yayasan Roqiba (Rhoudlatul Qori-Qori'ah Banten). 2015.

[4] Khasanah, Iswatun, dan Al Fatta Hanif. "Rancang Bangun Media Pembelajaran Tajwid Berbasis Multimedia". Jurnal DASI. Vol. 11, No. (4). 1411-3201, 2010.

[5] Luther, A. C., Authoring Interactive Multimedia, Academic Press, Inc., Massachusettes, 1994.

[6] Mayer, Richard E. Multimedia Learning Prinsip-Prinsip dan Aplikasi. Yogyakarta: Pustaka Pelajar; Surabaya: ITS Press, 2009.

[7] Mssraty,Tariq H. "Multimedia Instructional Learning System to Aid inTeaching Quran Recitation with Effective Tajweed in Primary Education of Malaysia". International Journal on Islamic Applications in Computer Science And Technology, Vol. 3, Issue 2, June 2015, 19-28. Faculty of Science and Technology, Universiti Sains Islam Malaysia (USIM), 2015.

[8] Adhayani, Ai dan Dewi Tresnawti. "Pengembangan Sistem Multimedia Pembelajaran Iqro' Menggunakan Metode Luther". Jurnal Al-goritma STT Garut vol 12 No.1, 2015. 